\title{
Pseudomarvania, gen. nov. (Chlorophyta, Trebouxiophyceae), a new genus for "budding" subaerial green algae Marvania aerophytica Neustupa et Š́JNOHOVÁ and Stichococcus ampulliformis HANDA
}

\author{
Marek ELIÁŠ \& Jiří NEUSTUPA* \\ Charles University in Prague, Faculty of Science, Department of Botany, Benátská 2, CZ-128 01 Praha 2, Czech \\ Republic; *corresponding author e-mail: neustupa@natur.cuni.cz
}

\begin{abstract}
Several unicellular green algae exhibit a unique type of cell division, which can be likened to budding. These algae comprise Spongiochrysis hawaiiensis in Cladophorales (Ulvophyceae) and Stichococcus ampulliformis and species of the genus Marvania in the class Trebouxiophyceae. We determined the 18S rRNA gene sequence from Marvania aerophytica NeustuPA et ŠejNOHOvá and inferred its phylogenetic position. Our analyses demonstrated that M. aerophytica is unrelated to other species of the genus Marvania (including the type species M. geminata), but together with S. ampulliformis forms a lineage within a broader clade comprising also species of the order Prasiolales, Desmococcus spp., Gloeotilla spp., and non-monophyletic Stichococcus spp. We discuss morphological characteristics of M. aerophytica and S. ampulliformis and based on our results, we propose M. aerophytica and S. ampulliformis be reclassified into a newly established genus of "budding" green algae, Pseudomarvania, as Pseudomarvania aerophytica, comb. nov. and Pseudomarvania ampulliformis, comb. nov.
\end{abstract}

Key words: evolution, Marvania, Stichococcus, phylogeny, Trebouxiophyceae, 18S rRNA

\section{Introduction}

Green algae exhibit a great diversity in the patterns of cell division (PicketT-Heaps 1975). An interesting form of cell reproduction was described by HINDÁK (1976) in a freshwater planktonic unicellular green alga described as Marvania geminata. Vegetative cells of $M$. geminata are spherical, but upon initiation of the reproductive process the cell starts bulging until the mother cell wall ruptures at the growing pole. The "bud" keeps expanding and when it reaches the dimensions of the part of the cell retained in the remnant of the mother cell wall, two separate cells are formed. Ultrastructural investigations of dividing $M$. geminata cells revealed that the "budding" is a highly modified form of autosporulation (REYMOND et al. 1986, SLUIMAN \& Reymond 1987, Yамамото et al. 2007) designated as semi-exogenous autosporogenesis (SLUIMAN \& REYMOND 1987).

The phylogenetic position of $M$. geminata was first illuminated by HenLey et al. (2004) with the use of $18 \mathrm{~S}$ rRNA gene sequences. This study showed that $M$. geminata is very closely related to a strain (CCAP 251/1b) previously considered to represent Nannochloris coccoides NAUMANN, and both taxa belong to a clade roughly corresponding to the traditional order Chlorellales. Based on this finding and given the light microscopical observations of YАМАМОТО et al. (2003) indicating that the strain CCAP 251/1b is morphologically very similar to $M$. geminata, HENLEY and colleagues reclassified $N$. coccoides as Marvania coccoides. However, as pointed out by TsCHERMAK-Woess (1999) and YамAMото et al. (2007), the strain CCAP 251/1b does not fit with the original description of the species $N$. coccoides by NAUMANN, hence the identity of the species M. "coccoides" is uncertain.

Stichococcus ampulliformis, described by HANDA et al. (2003) from a tree bark in Japan, extended the occurrence of the budding-like cytokinesis in green algae beyond the genus Marvania. This alga occasionally forms short moniliform filaments, but otherwise is quite unlike typical representatives of the genus Stichococcus. Electron microscopical investigations revealed that the "budding" is also a modified autosporulation with two autospores of highly unequal size formed within the mother cell wall. A phylogenetic analysis based on a partial 18S rRNA gene sequence indicated that 
S. ampulliformis is indeed related to Stichococcus species within the class Trebouxiophyceae, but the Stichococcus genus appeared paraphyletic owing to sequences from Prasiola spp. disrupting its monophyly (HANDA et al. 2003). Regardless the uncertainties about the precise relationship of S. ampulliformis to other Stichococcus species, it is clear that $S$. ampulliformis is not closely related to the genus Marvania.

Additional "budding" green alga, Spongiochrysis hawaiiensis, has recently been described from a terrestrial habitat on Hawaii, U.S.A. (RINDI et al. 2006). Analyses of $18 \mathrm{~S}$ rRNA gene sequences revealed that $S$. hawaiiensis belongs to the order Cladophorales in the class Ulvophyceae, and is thus even more distantly related to the genus Marvania than $S$. ampulliformis. All these results indicate that the budding-like form of cell division has evolved at least several times in the course of green algal phylogeny. It follows that "budding" of particular green algal species does not qualify them $a$ priori as close relatives and other features, especially molecular characters, must be taken into account when a phylogenetic position of such species is to be determined.

One species, on whose taxonomic and phylogenetic status was judged solely on the basis of the budding-like cytokinesis and in the absence of molecular data, was described from a subaerial habitat in tropical Malaysia (NEUSTUPA \& Š́ejnohová 2003). Since the genus Marvania was the only "budding" green algal taxon known at that time, the species was attributed to this genus as a new species, Marvania aerophytica. The taxonomic descriptions of M. aerophytica and $S$. ampulliformis were published independently at essentially the same time. Rindi et al. (2006) noted the morphological similarity of $M$. aerophytica and $S$. ampulliformis and suggested that these two algae might be conspecific. To resolve the taxonomic identity and phylogenetic position of $M$. aerophytica, we sequenced the 18S rRNA gene from the type strain and conducted a series of phylogenetic analyses. The results indicate that $M$. aerophytica and S. ampulliformis are distinct, yet related, species, which should be treated as a genus separate from other trebouxiophycean genera described so far.

\section{Materials and methods}

The cells of the CAUP H 7301 strain of Marvania aerophytica were cultured in agar-solidified BBM. For details of cultivation see Neustupa \& Š EJNOHOvá (2003). The cells were photographed using the Olympus BX51 light microscope and the Olympus Z5060 digital equipment using Nomarski differential contrast after 10 weeks of cultivation.

For isolation of genomic DNA, cells were scraped from an agar plate with a clean spatula, transferred into an Eppendorf tube, resuspended in distilled water and harvested by centrifugation. Total DNA was extracted using the Invisorb ${ }^{\circledR}$ Spin Plant Mini Kit (Invitek). The sequence of the 18S rRNA gene was determined by sequencing of two overlapping segments obtained by PCR amplification of the genomic DNA. The first segment was amplified by using the unpublished forward primer $34 \mathrm{~F}$ and the reverse primer $1650 \mathrm{Rmod}$, whose sequences were kindly shared with us by Prof. Thomas Friedl, University of Göttingen. The second segment was amplified using the forward primer 1500af (HeLms et al. 2001) and the reverse primer ITS4 (White et al. 1990). The PCR products were purified using the JETQUICK PCR Product Purification Spin Kit (Genomed). The first segment was sequenced from both ends using the amplification primers and internal sequencing primers from KatANA et al. (2001). The second segment was sequenced with the 1500af primer and the $18 \mathrm{~S}$ rRNA R primer from KataNa et al. (2001). Sequencing reactions were performed using the BigDye Terminator v3.1 Cycle Sequencing Kit (Applied Biosystems) and analysed with the 3130 Genetic Analyzer (Applied Biosystems). Sequencing reads were assembled with the CAP3 assembler server (http://pbil.univ-lyon1.fr/cap3.php), and the assembly was manually edited by visual inspection of sequencing chromatograms. The assembled sequence contains a gap in a region corresponding to an S934 intron, because the intron appears to be very long and the primers employed for sequencing did not allow reading through the whole intron. The 3' end of the sequence stops within an S1506 intron (we did not attempt to extend the sequence further downstream, because it would not provide any information relevant with respect of the aims of this study). The newly obtained 18S rDNA sequence of $M$. aerophytica CAUP H 7301 was deposited in GenBank with the accession number FJ896222.

Construction of multiple alignments including the newly determined $18 \mathrm{~S}$ rDNA sequence and the strategy used to select representative sequences for a broader phylogenetic analysis to determine the position of M. aerophytica were done as described previously (Neustupa et al. 2009). In addition, we prepared a second alignment comprising wide selection of sequences from the Stichococcus/Prasiola clade (see text and Fig. 3 ). For this analysis we omitted some highly similar 
sequences from the genera Prasiola and Rosenvingiella and one of the redundant sequences (EU434026.1) for Desmococcus endolithicus SAG 25.92, but otherwise we included all sequences from this clade available as of February 2009. Sequences from Coenocystis inconstans, Chlorella mirabilis Andreyeva 748-I, and representatives of the Raphidonema/Pseudochlorella clade were used as the outgroup for the Stichococcus/ Prasiola clade, following the results of the broader analysis. Maximum likelihood (ML) tree inferences were carried out with PhyML 3.0 (GUINDON \& GASCUEL 2003) operated at the ATGC bioinformatics platform (http://www.atgc-montpellier.fr/phyml/), employing the GTR $+\mathrm{F}+\mathrm{I}+\Gamma 8$ substitution model and the SRN \& NNI heuristics. ML bootstrap support was calculated from 100 bootstrap replicates. Evaluation of the tree topologies was also performed with the neighbour joining (NJ) method as implemented in the PHYLIP 3.6 package (FELSENSTEIN 2004). 1000 bootstrap replicates of the alignments were created with the seqboot programme and distance matrices were than inferred with the dnadist programme employing the F84 model of nucleotide evolution, transition/transversion ratio 2.0 , one rate category and no $\Gamma$ correction. NJ trees were inferred with the neighbor programme and consensus trees were obtained with the consense programme. Bayesian inference was also applied on the dataset centred on the Stichococcus/Prasiola clade. We employed the GTR $+\Gamma+\mathrm{I}$ substitution model (other settings were kept as default) and run the analysis for $1,200,000$ generations (sampling every $100^{\text {th }}$ generation) to reach convergence. The first 3001 (25\%) trees were discarded as burn-in and posterior probabilities of tree bipartitions were calculated from the remaining trees.

\section{Results}

In order to check the identity of the type strain of $M$. aerophytica maintained at the CAUP culture collection (as CAUP H 7301), we investigated with a light microscope its cell morphology and the pattern of division (Fig. 1). The morphology of the cells corresponded well to the original observations of the $\mathrm{H} 7301$ strain reported by Neustupa \& ŠEJnOHOVÁ (2003).

The region of the $18 \mathrm{~S}$ rRNA gene sequenced in this study comprises 1713 bp of the $18 \mathrm{~S}$ rRNA itself and two putative group I introns: an intron S943 (this intron is probably very long and we failed to determine its full sequence, leaving a gap in the assembly) and an intron S1506 (truncated at its 3' end). When the sequence (excluding the intron regions) was used as a query in BLASTN searches against the $n r$ database at NCBI (http:// blast.ncbi.nlm.nih.gov/), it gave as best hits
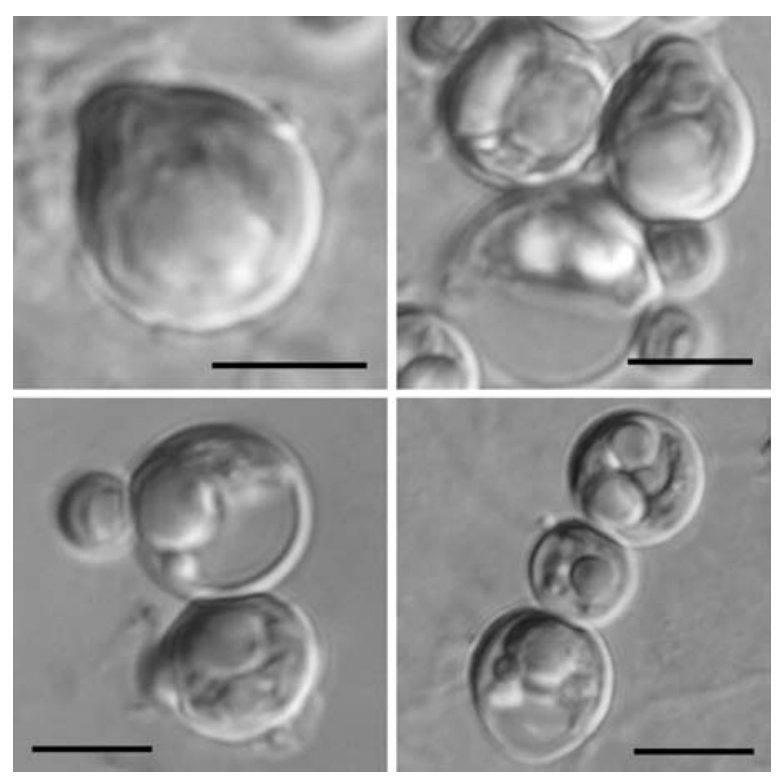

Fig. 1. Light microscopic morphology of Pseudomarvania (=Marvania) aerophytica CAUP H 7301. Scale bar $5 \mu \mathrm{m}$.

sequences previously shown to belong to a common clade comprising genera Stichococcus, Raphidonema, Prasiola and relatives in the green algal class Trebouxiophyceae (HANDA et al. 2003, Karsten et al. 2005, Neustupa et al. 2007, Sluiman et al. 2008, Mikhailyuk et al. 2008). The level of similarity of these sequences to the query was up to $97 \%$ identity in pairwise alignments, indicating that $M$. aerophytica is probably related to this clade.

A phylogenetic analysis performed with a selection of representative trebouxiophycean sequences (Fig. 2) recovered this clade (here referred to as the Stichococcus/Raphidonema clade) with strong bootstrap values. M. aerophytica was nested within a moderately supported subclade of the Stichococcus/Raphidonema clade (designated as the Stichococcus/Prasiola clade in Fig. 2) and formed a moderately supported lineage together with $S$. ampulliformis. In contrast, $M$. geminata (the type species of the genus Marvania) together with $M$. "coccoides" and an unidentified strain designated as Marvania sp. JL 11-11 (morphologically corresponding to $M$. geminata and having an identical 18S rRNA gene sequence as M. "coccoides", see HenLEY et al. 2004) formed a strongly supported tight clade elsewhere in the tree (as a part of a larger clade that can be equated with the order Chlorellales). In order to define the phylogenetic position of $M$. aerophytica more precisely, we conducted a second analysis focusing on the Stichococcus/Prasiola clade (Fig. 


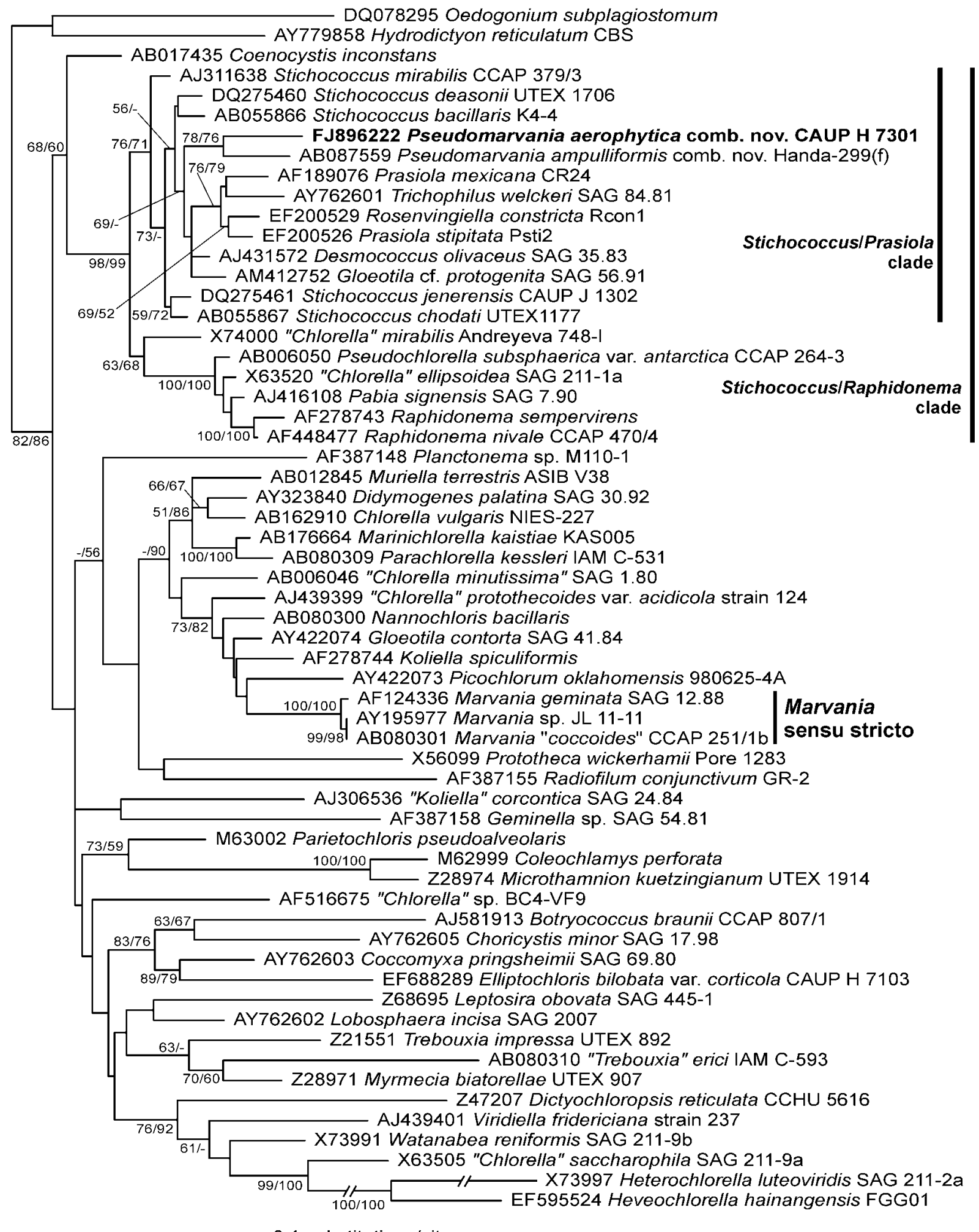

0.1 substitutions/site

Fig. 2. Phylogenetic position of Pseudomarvania (=Marvania) aerophytica CAUP H 7301 within Trebouxiophyceae inferred from 18S rRNA gene sequences (1730 positions) with the maximum likelihood method (PhyML 3.0; GTR $+\mathrm{F}+\mathrm{I}+\Gamma 8, \log 1 \mathrm{k}$ $=-12136.43093, \alpha=0.358$, proportion of invariant sites $=0.435)$. Sequences from Oedogonium subplagiostomum and Hydrodictyon reticulatum (Chlorophyceae) are used to root the tree. Numbers at branches indicate ML/NJ bootstrap support values (only values higher than 50 are shown). Branches with double breaks were shortened to their halves to fit them into the figure. The sequence determined in this study is highlighted in bold. 


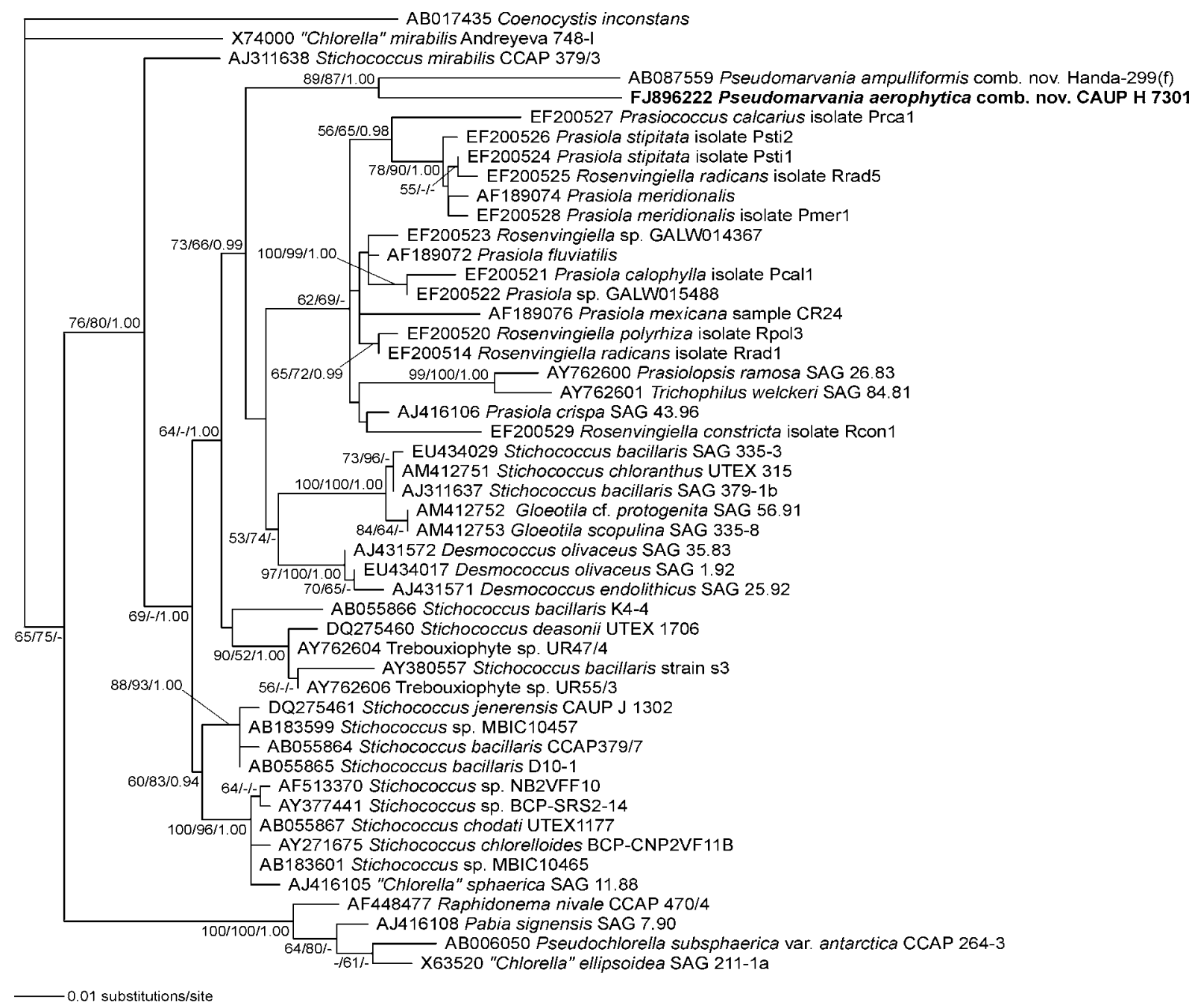

Fig. 3. Maximum likelihood 18S rDNA phylogenetic tree (based on 1731 positions) of the Stichococcus/Prasiola clade and closest relatives (PhyML 3.0; GTR $+\mathrm{F}+\mathrm{I}+\Gamma 8, \log \mathrm{k}=-4621.91596, \alpha=0.389$, proportion of invariant sites $=0.686$ ). Numbers at branches refer to $\mathrm{ML} / \mathrm{NJ}$ bootstrap support values/Bayesian posterior probabilities. The tree is rooted with the sequence from Coenocystis inconstans, following the topology of the tree in Fig. 1.

3). In the resulting ML tree, M. aerophytica and $S$. ampulliformis also formed a common lineage to the exclusion of all other available representatives of the Stichococcus/Prasiola clade, with a stronger bootstrap support (89/87 from ML/NJ) compared to the previous analysis. We also obtained a Bayesian tree for this smaller dataset and recovered the $M$. aerophytica/S. ampulliformis branch with posterior probability of 1.00 .

Despite the close relationship of $M$. aerophytica and S. ampulliformis suggested by these analyses, their 18S rRNA sequences are not particularly similar, exhibiting identity at only 1584 out of 1625 positions in a pairwise alignment (two positions in the $S$. ampulliformis sequence available are ambiguous). Furthermore, the $S$. ampulliformis 18S rRNA gene lacks an S943 intron (whether its does or does not contain an S1506 intron is unknown, because the sequence available does not extend to the corresponding region of the gene).

\section{Discussion}

The major question addressed in this study was whether the original assignment of $M$. aerophytica to the genus Marvania is tenable. The answer provided by our analyses appears unequivocal. The phylogenetic position of the true Marvania, represented by the type species $M$. geminata, the closely related $M$. "coccoides", and the unspecified strain Marvania sp. JL 11-11, has been recovered within a part of the trebouxiophycean tree identifiable as the order Chlorellales, fully in agreement with results reported by HeNLEY et 
al. (2004). In contrast, M. aerophytica is nested within a different and strongly supported clade of the Trebouxiophyceae, the Stichococcus/ Raphidonema clade, and specifically in its (lesswell supported) Stichococcus/Prasiola subclade (Fig. 1). Hence, in phylogenetic terms, $M$. aerophytica is very distant to the true Marvania species.

RINDI et al. (2006) hypothesized that $M$. aerophytica and $S$. ampulliformis may be conspecific. However, the similarity level of $18 \mathrm{~S}$ rRNA sequences of these two strains $(97 \%$ similarity, at least 39 base differences) indicates a probable very long period of independent evolution. As far as we are aware, such divergence has not been observed for conspecific strains of any green algal group for which the species concept is well established. Nevertheless, both species are morphologically very similar, even if their phenotypic differentiation remains to be investigated in a comparative morphological study. However, even the available morphological data on these species (HANDA et al. 2003, NEUSTUPA \& ŠEJNOHOVÁ 2003; this study) indicate slight, yet discernible, differences. Especially, we have not observed in M. aerophytica cultures formation of moniliform filamentous branches reported for $S$. ampulliformis (HANDA et al. 2003). Nevertheless, it should be stated that based on the present data, the relationships at species level between both species remains unclear. More variable molecular markers and comparative morphological data will be necessary to clarify them. However, as a provisional solution, it is chosen to maintain them as separate species that probably are closely related within Trebouxiophyceae. Both in the broadly sampled trebouxiophycean tree (Fig. 1) and in the comprehensive tree of the Stichococcus/ Prasiola clade (Fig. 2), M. aerophytica and $S$. ampulliformis are mutual sister branches, with considerable statistical support from both the ML and the NJ analyses (over 70\% in the first tree and over $80 \%$ in the second tree) and with maximal support (posterior probability of 1.00 ) from the Bayesian analysis of the Stichococcus/ Prasiola clade. It is noteworthy that the $18 \mathrm{~S}$ rRNA gene sequence available for $S$. ampulliformis is partial and does not cover the 3' end of the gene (the last $\approx 80$ bp of a region routinely amplified with universal $18 \mathrm{~S}$ rRNA gene primers), so it is possible that ML and NJ bootstrap support for the $M$. aerophytica/S. ampulliformis lineage would be even higher if the missing characters could be included in the analysis. Together with the shared morphological peculiarities of M. aerophytica and $S$. ampulliformis, particularly the unique mode of cell division, it seems reasonable to assume that these two species share a common ancestor exclusive with respect to other currently sampled representatives of the Stichococcus/Prasiola clade. The exact position of the M. aerophytica/S. ampulliformis lineage in the Stichococcus/Prasiola clade remains uncertain at present, since the $18 \mathrm{~S}$ rRNA gene alone apparently does not provide enough phylogenetic signal to unambiguously resolve the branching order within the clade. The only conclusion that can be drawn from the present analysis is that there is no obvious close relative of the M. aerophytica/S. ampulliformis lineage (Fig. 2). Analyses of multiple molecular markers and eventual future addition of other related taxa, possibly occurring in subaerial habitats of subtropical and tropical regions, will hopefully shed more light on the phylogenetic history of these algae.

Our results provide a basis for reconsidering the generic status of both $M$. aerophytica and $S$. ampulliformis. Given the relationship indicated by the 18S rRNA gene sequences and very similar morphological characteristics, it seems most appropriate to treat these species as representatives of the same genus. As explained above, this cannot be the genus Marvania HINDÁK. Hence, an option that might be considered is to reclassify $M$. aerophytica into the genus Stichococcus NäGELI. However, we think that the assignment of $S$. ampulliformis itself in the genus Stichococcus is problematic. Consistently with previous studies (Handa et al. 2003, Neustupa et al. 2007), species currently assigned to the genus Stichococcus constitute several separate lineages in our $18 \mathrm{~S}$ rRNA gene tree, rendering the genus paraphyletic. Although it is possible that the paraphyly observed has partly been due to inability of the $18 \mathrm{~S}$ rRNA gene to reproduce the true phylogenetic history of the Stichococcus/Prasiola clade and future multigene analyses will yield different topologies showing most nominal Stichococcus species in one large monophyletic clade, it seems that the current circumscription of the genus Stichococcus is too broad and underestimates the actual diversity of the species included. For example, it is unlikely that the three Stichococcus taxa ( $S$. bacillaris SAG 335-3, S. bacillaris SAG 379-1b, and $S$. chloranthus UTEX 315) clustering with firm support with two strains attributed to the genus 
Gloeotila (G. scopulina SAG 335-8 and G. cf. protogenita SAG 56.91; see Fig. 2) are actually more closely related to the remaining Stichococcus strains. Strikingly, the name of the type species of the genus Stichococcus, S. bacillaris, has been attached to diverse strains representing at least four separate lineages in the 18S rRNA tree, documenting substantial hidden genetic diversity within this single morphotype. In the future one particular strain, preferably such that best fits with the original description of $S$. bacillaris by NÄGELI, should be selected as a lectotype (the original strain has not been preserved) and the genus Stichococcus should be redefined as a monophyletic lineage comprising this strain and its relatives. However, no "S. bacillaris" strain appears to be closely related to the $M$. aerophytica/S. ampulliformis lineage (Fig. 2), so there is presently no evidence that this lineage belongs phylogenetically to the "true" Stichococcus genus. This notion is further strengthened by the apparent morphological disparity between the spherical or subspherical cells of $M$. aerophytica and $S$. ampulliformis reproducing by budding-like, highly asymmetric autosporogenesis (HANDA et al., 2003, NEUSTUPA \& Š́sNohová, 2003) and between the typically bacilliform cells of Stichococcus reproducing by vegetative cell division. We therefore conclude that the assignment of $S$. ampulliformis to the genus Stichococcus suggested by Handa et al. (2003) was inappropriate, a view that was previously put forth by Rindi et al. (2006).

Since we are unaware of any previously established genus of green algae that would exhibit characters typical for $M$. aerophytica and $S$. ampulliformis (especially the unique budding-like mode of cytokinesis) and that would at the same time be potentially related to these two species (both Marvania HINDÁk and Spongiochrysis Rindi, LóPez-BAUTISTA, SHERWOOd et GUIRY are demonstrably unrelated, see above), we propose that a new genus, Pseudomarvania, be established to accommodate $M$. aerophytica and $S$. ampulliformis (diagnosis provided below). This new genus can be readily defined by a suite of characters, which clearly differentiate it from the genus Marvania. First, in Pseudomarvania, the mother cell wall ruptures only after new cell wall is formed enclosing the two incipient cells (Handa et al. 2003, Neustupa \& ŠEjnOHOVÁ 2003). In Marvania, by contrast, the "bud" that grows out through the break in the mother cell wall is just an expanding part of the cell residing in the remnant of the mother cell wall; the whole expanding protoplast is enclosed in a newly deposited cell wall and mitosis and subsequent cell division (by means of eleutheroschisis, i.e. deposition of yet another cell wall layer) occurs only when the "bud" is of about the size of the "mother cell" (HINDÁk 1976, REYMOND et al. 1986, Sluiman \& Reymond 1987, Yamamoto et al. 2007). Next, in Pseudomarvania, the daughter cell that "buds off" is much smaller than the mother cell (Handa et al. 2003, Neustupa \& Šejnohová 2003), whereas in Marvania the two cells are of approximately equal size when their separation takes place (HindÁk 1976, REYMOND et al. 1986, SLuiman \& Reymond 1987). Third, the cell wall of Pseudomarvania is smooth (HANDA et al. 2003, Neustupa \& Š́sNohová 2003), but the cell wall of Marvania is decorated by electrondense warts (HindÁk 1976, ReYmond et al. 1986). Finally, the genus Marvania comprises freshwater organisms, whereas both species of the newly described genus Pseudomarvania were isolated from the subaerial microhabitats of tree bark surface in tropical and subtropical regions of East Asia (HANDA et al. 2003, Neustupa \& Šejnohová 2003, Henley et al. (2004). Certainly, we cannot preclude much broader distribution of the genus, but the twofold discovery of Pseudomarvania species in warm-temperature environments and the lack of evidence for Pseudomarvania in temperate subaerial corticolous growths indicates possible specific affinity of Pseudomarvania to subtropical and tropical ecosystems.

In summary, we found that $M$. aerophytica can no longer be maintained as a species of the genus Marvania, because its phylogenetic position is very remote from the type species of the genus. Instead, it is related to, yet distinct from, S. ampulliformis, and these two algae form a new genus-level lineage within the Stichococcus/Prasiola clade. To remedy the untenable generic assignments of both M. aerophytica and S. ampulliformis, we establish a new genus, Pseudomarvania Eliáš \& Neustupa, and transfer both species into this genus as new combinations Pseudomarvania aerophytica and Pseudomarvania ampulliformis. By removing $S$. ampulliformis from the genus Stichococcus we initiated a process of revising the concept of this genus, which is likely to continue with excluding further species and establishing new genera. 


\section{Diagnosis}

\section{Pseudomarvania Eliáš et Neustupa, gen. nov.}

Diagnosis: Microalgae virides terricolae. Cellulae vegetativae sphaericae vel subsphaericae, uninucleatae, solitariae vel filamenta brevia formans. Paries cellulae laevis. Chloroplastus singulus, parietalis, patelliformis, sine pyrenoide. Propagatio asexualis cellularum divisione protoplasti in partes duas, germinationi similes videntur; cellulae-filiae dimensione differentes. Flagella nulla. Reproductio sexualis ignota.

Typus generis: Pseudomarvania aerophytica (NEUSTUPA \& Šejnohová) Eliáš \& Neustupa, comb. nov.

Description: Green microalgae from terrestrial habitats. Vegetative cells spherical or subsphaerical, uninucleate, solitary or forming short filaments. Cell wall smooth. Chloroplast single, parietal, cup-shaped, without pyrenoids. Asexual propagation of cells by division of the protoplast into two parts in a budding-like mode; daughter cells of unequal size. Flagella absent. Sexual reproduction unknown.

Etymology: from Greek pseudo (false) and Marvania (a name of a genus of unrelated but morphologically similar green algae).

The genus Pseudomarvania comprises the following species:

Pseudomarvania aerophytica (Neustupa et

Š́tnohová) Eliáš et Neustupa, comb. nov.

BASIONYM: Marvania aerophytica NeUstupa et Š́JNOHOVÁ 2003, in Biologia 58: 503-507.

Pseudomarvania ampulliformis (HANDA) ELIÁš et

Neustupa, comb. nov.

BASIONYM: Stichococcus ampulliformis HANDA 2003, in Handa et al., Phycol. Res. 51: 203-210.

\section{Acknowledgements}

We thank Veronika Kučabová for her excellent technical assistance. We are also grateful to Prof. Thomas Friedl for sharing with us unpublished primer sequences, to Dr. Fabio Rindi for his valuable comments that led us to improvements of the manuscript, and to Prof. Georg Gärtner for the corrections of Latin diagnoses. This work has been supported by the grant no. 206/06/0998 of the Czech Science Foundation and by the research project no. 21620828 of Czech Ministry of Education.

\section{References}

Felsenstein, J. (2004): PHYLIP (Phylogeny Inference Package) version 3.6. - Department of Genome Sciences, University of Washington, Seattle.

Guindon, S. \& Gascuel, O. (2003): A simple, fast, and accurate algorithm to estimate large phylogenies by maximum likelihood. - Systematic Biology 52: 696-704.

Handa, S., Nakahara, M., Tsubota, H. Deguchi, H. \& NAKANO, T. (2003): A new aerial alga, Stichococcus ampulliformis sp. nov. (Trebouxiophyceae, Chlorophyta) from Japan. - Phycological Research 51: 203-210.

Helms, G., Friedl, T., Rambold, G. \& Mayrhofer, H. (2001): Identification of photobionts from the lichen family Physciaceae using algal-specific ITS rDNA sequencing. - Lichenologist 33: 73-86.

Henley, W.J, Hironaka, J.L., Gulllou, L., Buchheim, M.A., Buchheim, J.A., Fawley, M.W. \& FAWLEY, K.P. (2004): Phylogenetic analysis of the 'Nannochloris-like' algae and diagnoses of Picochlorum oklahomensis gen. et sp. nov. (Trebouxiophyceae, Chlorophyta). - Phycologia 43: 641-652.

Hindék, F. (1976): Marvania geminata gen. nov. et sp. nov., a new green alga. - Algological Studies 16: $261-270$.

Karsten, U., Friedl, T., Schumann, R., Hoyer, K. \& LEMBECKE, S. (2005): Mycosporine-like amino acids and phylogenies in green algae: Prasiola and its relatives from the Trebouxiophyceae (Chlorophyta). - Journal of Phycology 41: 557-566.

Katana A., Kwiatowski J., Spalik K., Zakrys B., Szalacha E. \& Szymanska H. (2001): Phylogenetic position of Koliella (Chlorophyta) as inferred from nuclear and chloroplast small subunit rDNA. - Journal of Phycology 37: 443-451.

Mikhailyuk, T.I., Sluiman, H.J., Massalski, A., Mudimu, O., Demchenko, E.M., Kondratyuk, S.Y. \& FrIEDL, T. (2008): New streptophyte green algae from terrestrial habitats and an assessment of the genus Interfilum (Klebsormidiophyceae, Streptophyta). - Journal of Phycology 44: 1586-1603.

Neustupa, J. \& Š́̇JnohovÁ, L. (2003): Marvania aerophytica sp. nov., a new subaerial tropical green alga. - Biologia 58: 503-507.

Neustupa, J., Eliáš, M \& Šejnohová, L. (2007): A taxonomic study of two Stichococcus species (Trebouxiophyceae, Chlorophyta) with a starch-enveloped pyrenoid. - Nova Hedwigia 84: 51-63.

Neustupa, J., NĚmcová, Y., Eliáš, M. \& Škaloud, P. (2009): Kalinella bambusicola gen. et sp. nov. (Trebouxiophyceae, Chlorophyta), a novel coccoid Chlorella-like subaerial alga from Southeast Asia. - Phycological Research, in press.

Pickett-Heaps, J. (1975): Green Algae: Structure, Reproduction and Evolution in Selected Genera. - 606 pp. Sinauer Assoc., Stamford, CT. 
Reymond, O.L., Hindák, F. \& Sluiman, H.J. (1986): Morphologie cellulaire et cycle de développement chez l'algue verte Marvania geminata HindÁK. - Archives des Sciences, Genève 39: 243-255.

Rindi, F., López-Bautista, J.M., Sherwood, A.R. \& GuiRY, M.D. (2006): Morphology and phylogenetic position of Spongiochrysis hawaiiensis gen. et sp. nov., the first known terrestrial member of the order Cladophorales (Ulvophyceae, Chlorophyta). - International Journal of Systematic and Evolutionary Microbiology 56: 913-922.

Sluiman, H.J. \& Reymond, O.L. (1987): Cell division in the green microalga Marvania geminata: semiexogenous autosporogenesis, role of coated pit-microtubule complexes and systematic significance. - Acta Botanica Neerlandica 36: 231-245.

Sluiman, H.J., Guihal, C. \& Mudimu, O. (2008): Assessing phylogenetic affinities and species delimitations in Klebsormidiales (Streptophyta): Nuclear-encoded rDNA phylogenies and its secondary structure models in Klebsormidium, Hormidiella, and Entransia. - Journal of Phycology 44: 183-195.

Tschermak-Woess, E. (1999): Life cycle and supplementary comments on the light microscopical morphology of Nannochloris eucaryota. - Plant Biology 1: 214-218.

White, T.J., Bruns, T., Lee, S. \& TAylor, J.W. (1990): Amplification and direct sequencing of fungal ribosomal RNA genes for phylogenetics. - In: Innis, M.A., Gelfand, D.H. Sninsky, J.J. \& White, T. J. (eds): PCR Protocols: A Guide to Methods and Applications. - pp. 315-322, Academic Press, Inc., New York.

Yamamoto, M., Nishikawa, T., Kajitani, H. \& Kawano, S. (2007): Patterns of asexual reproduction in Nannochloris bacillaris and Marvania geminata (Chlorophyta, Trebouxiophyceae). Planta 226: 917-927.

Yamamoto, M., Nozaki, H., Miyazawa, Y., Koide, T. \& KaWANO, S. (2003): Relationship between presence of a mother cell wall and speciation in the unicellular microalga Nannochloris (Chlorophyta). - Journal of Phycology 39: 172-184.

(C) Czech Phycological Society

Received April 20, 2009

Accepted June 1, 2009 

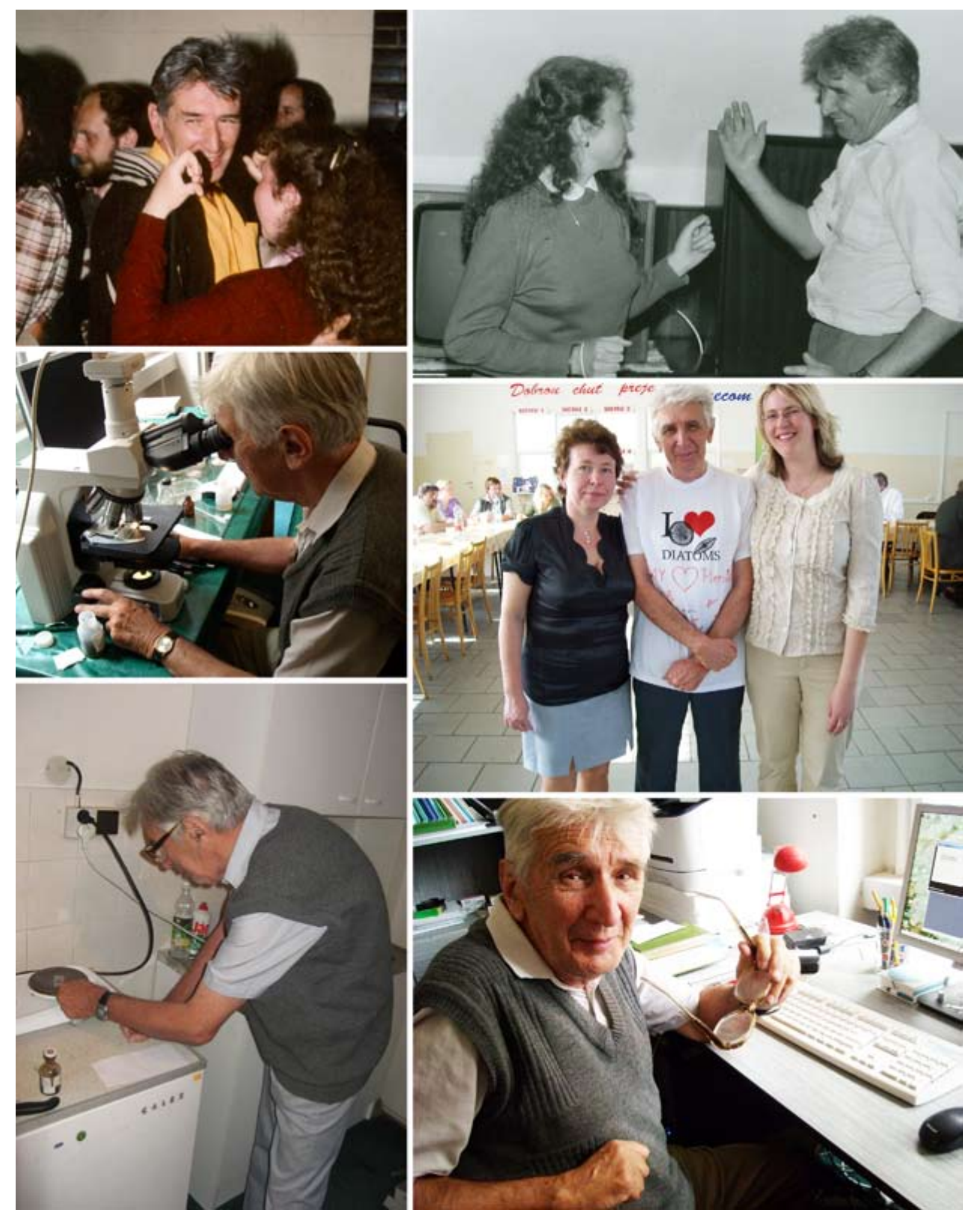